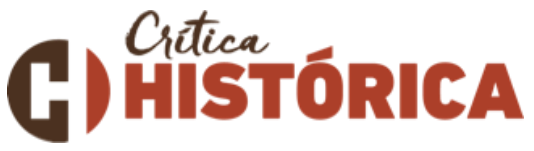

\section{O fim do marxismo na historiografia brasileira?}

\author{
Is it the end of Marxism in Brazilian historiography?
}

Ronaldo P. de Jesus*

\begin{abstract}
Resumo: O artigo apresenta um panorama do desempenho e da influência do marxismo na historiografia brasileira entre os anos de 1930 e I990. O objetivo é compreender a dimensão da influência predominante que o materialismo histórico, enquanto expressão teórica e a prática política, alcançou ao longo do século XX. E delimitar os condicionantes do declínio constante da influência do marxismo sobre os historiadores no Brasil a partir de meados dos anos de 1980.
\end{abstract}

Palavras-chave: Historiografia brasileira; Marxismo; Materialismo histórico.

Abstract: The article presents a general approach concerning the influence and the performance of marxism in the brazilian historiography between 1930 and 1990. The purpose is to understand the dimension of the predominant influence which the historical materialism, both as theoretical expression as political practice, got during the twentieth century. And define the conditions of the steady decline of the marxism influence among historians in Brazil since the mid -I980s.

Keywords: Brazilian historiography; Marxism; Historical materialism.

\section{As crises dos marxismos}

In the tracks of Historical Materialism (1983), publicado no Brasil em 1984, trouxe a público três conferências - Predição e Desempenho, Estrutura e Sujeito, Natureza e História - proferidas por Perry Anderson no Programa de Teoria Crítica da Universidade da Califórnia, acrescidas de um pequeno Prefácio e um Post-Scriptum. Trata-se de uma espécie de balanço das mudanças e desenvolvimentos intelectuais ocorridos entre os anos de 1970 e 1980, que remete a outro trabalho de Anderson, escrito em 1974 e publicado em 1976, Considerations on Western Marxism. Este último, editado em português somente em 1989, expõe de modo sistemático a evolução do marxismo na Europa Ocidental desde a Primeira Guerra Mundial.

O título que In the tracks of Historical Materialism recebeu na primeira edição brasileira, A crise da crise do marxismo, fez com que parecesse mais otimista do que realmente

\footnotetext{
" Doutor em História pela Universidade de São Paulo (USP). Professor Associado da Universidade Federal de Juiz de Fora - MG.
} 


\section{C) Gitcastórica}

era. E não se pode acusar a tradução, mais que livre, de ter sido meramente uma estratégia de propaganda com vistas a capturar os intelectuais marxistas brasileiros a qualquer preço. Pois, estes já eram leitores fiéis das publicações da Editora Brasiliense, uma das mais sérias e importantes do modesto mercado editorial à época.

Além disso, a expressão "crise da crise", que dimensiona ao mesmo tempo otimismo e ironia principalmente, foi retirada do próprio livro, da passagem em que Anderson se refere - no capítulo Predições e Desempenho - à maneira afoita e triunfalista com que a revista Time anunciava o fim do marxismo em I977, tomando como referência Considerations on Western Marxism, em que se vislumbrava a crise do chamado marxismo ocidental. Ironicamente, a crise não consistia no fim do marxismo, como sugeria a grande imprensa americana, mas sim, na retomada do vigor do marxismo, que renascia nos países de língua inglesa voltado para os temas clássicos da economia política. Era, portanto, o fim da crise e não o fim do marxismo.

Perry Anderson produziu desde então outras predições, diagnósticos e prognósticos, acerca do panorama intelectual ocidental e da dimensão específica do marxismo dentro dele. Sua crítica ao pensamento pós-moderno, ao lado de Frederic Jameson, Terry Eagleton e Josep Fontana, ainda manifesta a ironia ácida e o otimismo inerente a qualquer pensamento que se pretenda genuinamente marxista e revolucionário.

Entretanto, no que diz respeito ao marxismo propriamente dito, entendido como expressão teórica e política no âmbito da cultura ocidental, não se pode dizer com tanta certeza hoje que não esteja em crise. Embora, pareça sempre que, para além de emprestar os elementos conceituais mais adequados no combate ao pensamento hegemônico pósmoderno, dentro e fora do ambiente acadêmico, o marxismo ainda poderá renascer, reinventar-se e se fortalecer como já aconteceu no século XX.

$\mathrm{O}$ apego reiterado do pensamento marxista à autocrítica transforma a crise em condição permanente, mas que aponta também permanentemente a possibilidade de superação e aprimoramento. No entanto, no âmbito específico da relação entre o marxismo e a produção historiográfica o quadro de crise estrutural e renovação torna-se bem mais nebuloso, impreciso. As dificuldades de diagnóstico e predição relativas à influência e à importância do marxismo parecem quase intransponíveis quando se avalia o universo ainda mais restrito da historiografia brasileira.

Nota-se hoje que, provavelmente, poucos historiadores no Brasil concordariam publicamente em ser chamados de marxistas. Outros pouquíssimos ficariam decepcionados se não fossem. E muitíssimos outros, a grande maioria, ficariam possessos caso fossem acusados de ser. Pois, é inegável que nos últimos vinte e cinco anos o marxismo perdeu 


\section{C) Histótórica}

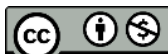

drasticamente a magnitude da influência que exercia sobre os historiadores no Brasil, enquanto modelo teórico.

Mais que isso. Aparentemente, os historiadores marxistas brasileiros, em número diminuto e completamente subordinados à hegemonia absoluta do capitalismo e da democracia liberal, manifestam a atitude que Slavoj Žižek classifica de "aceitação da inutilidade temporária da luta". Cujo desdobramento político consiste em defender o que ainda resta da possibilidade de se construir um Estado de bem-estar social, bombardear os governantes com exigências que se sabe não podem ser atendidas e refugiar-se nos estudos culturais, onde é possível realizar o trabalho crítico em silêncio, à espera da renovação do espírito revolucionário da classe trabalhadora global (ŽIŽEK 2009, p. 345).

Impossível predizer quantos aceitariam tal classificação e quais os que a repudiariam veementemente em público.

Entretanto, após três décadas de crise, o predomínio evidente da influência do marxismo na historiografia brasileira, ao longo do século $\mathrm{XX}$, parece completa e irreversivelmente superado e aponta simplesmente para o fim de uma tradição historiográfica. Nesse sentido, vivencia-se uma realidade muito diferente do que seria uma "crise da crise", como sinônimo de crise de ruptura e regeneração. Há ainda algo de paradoxal no fato de que a maioria esmagadora dos historiadores no Brasil, embora não se considere marxista, declara-se publicamente de esquerda, por exemplo, nas redes sociais.

Porém, antes de jogar a última pá de cal sobre o cadáver da historiografia marxista brasileira, vale a pena observar mais detidamente sua identidade e trajetória, para que se possa entender melhor a dimensão da crise, ou da crise da crise, ou do seu presumível fim.

\section{Historiografia brasileira e marxismos no século XX}

Embora haja indícios de referências diretas às obras de Marx e Engels na produção de jornalistas, políticos e letrados, entre finais do século XIX e início do século XX (MORAES FILHO 199I, p. I5-46; BATALHA 1995, p. II-44), parece consensual que a influência do marxismo na produção historiográfica no Brasil ocorreu de fato a partir dos anos de 1930. Nesse período, jovens militantes e intelectuais de esquerda, que figurariam entre os principais agentes da reflexão política e acadêmica nas três décadas posteriores, estavam envolvidos numa atmosfera de mudança coletiva da percepção que possuíam acerca do país e, principalmente, de alteração no modo como avaliavam a posição que o Brasil ocupava no contexto geopolítico mundial. 


\section{C) Hitsistórica}

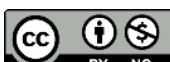

Entre 1930 e 1940 ocorreria uma substancial transformação nas formulações que

tradicionalmente abordavam o problema do atraso ou do arcaísmo da sociedade brasileira em comparação com os chamados países civilizados do ocidente. Cada vez mais, e adiante quase tão somente, o eixo central da prática política e da reflexão acadêmica passaria a ser menos o atraso e o arcaísmo e mais o problema conceitual e político da dependência e do subdesenvolvimento.

Entre I928 e I929, o III Congresso do Partido Comunista Brasileiro (PCB) apresentava um conjunto de teses em que o Brasil figurava como país subordinado ao imperialismo, apesar da independência política e do desenvolvimento da indústria em polos isolados, que havia originado um proletariado urbano combativo. Predominaria, portanto, uma espécie de configuração semicolonial, em que a industrialização via-se constantemente bloqueada pelo caráter eminentemente agrário da economia, baseada na exploração latifundiária das massas camponesas. A burguesia nacional, por sua vez, se encontraria completamente a mercê dos desígnios do imperialismo e do latifúndio no poder, agravando assim a exploração dos trabalhadores, do campo e da cidade, e da pequena burguesia. Estes três últimos seriam os agentes da primeira etapa da revolução que preconizava a solução radical do problema agrário, a superação das relações semifeudais e a supressão do julgo do capital estrangeiro (ZAIDÁN, I99I, p. 99-IO0).

Tais elementos compunham uma gama de possíveis sínteses analíticas, de inspiração marxista, disponíveis na década de 1930. Posteriormente, as teses sofreriam uma série de reformulações em resposta às diversas conjunturas internas e externas avaliadas pelo PCB. No entanto, pode-se dizer que as teses apresentavam uma espécie de resumo, não somente das questões práticas e políticas a serem enfrentadas naquele momento como também das questões conceituais que se impunham ao pensamento da esquerda. Tanto que feudalismo, capitalismo, imperialismo, colonialismo, agrarismo, industrialismo, bloco operáriocamponês e revolução burguesa permaneceriam na pauta das ciências sociais no Brasil pelo menos entre as décadas de 1940 e 1980.

A reflexão marxista propriamente historiográfica, acerca da natureza do processo de colonização da América portuguesa, sobre as características da economia, do Estado e da sociedade, emergia naquele momento profundamente influenciada pela ideia de convivência paradoxal entre dois "Brasis", um deles arcaico, rural, atrasado economicamente e outro industrial e desenvolvido resultante da modernização levada a cabo pelo governo Vargas no pós-1930 (BASTIDE 1959; LAMBERT 1967; ARANTES 1992.). Além disso, o debate historiográfico remetia às clássicas controvérsias em torno da transição do feudalismo para o capitalismo que envolveram autores como Henri Pirenne, Fernad 
Braudel, Paul Sweesy, Maurice Dobb, Christopher Hill, Rodney Hilton, Pierre Vilar e Immanuel Wallerstein entre muitos outros.

Sob a influência do marxismo, portanto, os historiadores brasileiros foram instigados, num primeiro momento, a refletir sobre as heranças do passado colonial. O maior desafio consistia em articular a tensão analítica em torno da combinação de elementos conceituais díspares ou conflitantes como, por exemplo, a inserção do Brasil na economia mundial capitalista na Época Moderna e a reinvenção da escravidão no Novo Mundo. A solução recairia na ênfase, maior ou menor dos autores, em caracterizar o universo colonial como um modo de produção autônomo, em relação ao processo inacabado de transição pelo qual passava a Europa, ou conceber a colônia como extensão do modo de produção capitalista supostamente em funcionamento a partir do século XVI.

Na prática, ao longo de décadas, o debate acadêmico parecia desenrolar-se em torno da suposta capacidade dos autores de interpretar mais ou menos corretamente a categoria modo de produção e os capítulos XXIV e XXV de O Capital, relativos à acumulação primitiva e ao colonialismo.

Nelson Werneck Sodré (I958, I962, 1964) e Alberto Passos Guimarães (1964) permaneceram mais atrelados às formulações do $\mathrm{PCB}$, na medida em que se apegavam às noções que remetiam ao "etapismo" inerente ao marxismo chamado ortodoxo. Enfatizavam o caráter escravista da economia colonial e destacavam os elementos do feudalismo que aparentemente haviam sido transplantados para o chamado Brasil colonial. Em posição completamente oposta, Caio Prado Jr. apresentava um exercício historiográfico sistemático cujo eixo central consiste na tentativa de adequar os princípios do materialismo histórico à realidade brasileira, para além das concepções amplas e difusas que apareciam sintetizadas nas teses do comunismo oficial.

Formação do Brasil contemporâneo (1942) é sem dúvida, até hoje, um dos mais importantes livros de história do Brasil. O impacto da abordagem oferecida por Caio Prado Jr. impressiona, visto em perspectiva, pela capacidade que logrou de criar uma tradição analítica que se realimenta ao longo de décadas, tendo inaugurado, na prática, uma espécie de escola de pensamento sobre o Brasil colonial. Como consequência, trata-se seguramente de um dos livros mais lidos pelos estudantes de graduação em História de todo Brasil. E, o mais impressionante, é que na maioria das vezes é lido não somente como elemento necessário para o entendimento da história da historiografia, mas principalmente como texto de conteúdo empírico e acabamento conceitual e analítico ainda amplamente aceitos pela comunidade acadêmica. 


\section{C) HitistóñICA}

Além de fornecer elementos empíricos indispensáveis para a compreensão do processo de povoamento e administração da América portuguesa, de equacionar a relação entre o poder público e o universo privado na colônia, Caio Prado Jr. desenvolveu um aporte analítico, até então inédito, que viria a ser seu legado mais duradouro e profícuo. "O sentido da colonização" edifica um dos capítulos mais importantes da historiografia brasileira, marxista ou não. Nele se concebe a economia colonial como empresa capitalista desde sua fundação porque integrada ao processo de acumulação primitiva do capital na Europa. A história do Brasil colonial, e de resto até meados do século $\mathrm{XX}$, se apresenta como processo de constituição de um anexo atrelado ao desenvolvimento econômico e político externo, forjado, segundo a célebre formulação, para fornecer açúcar, tabaco, ouro e diamantes, depois algodão e café para o comércio europeu.

Tal perspectiva, aberta no debate sobre a formação econômica e a administração da América portuguesa, agregou um conjunto significativo de autores - Celso Furtado (I959), Fernando Henrique Cardoso (1962), Fernando Antônio Novais (1978) José Jobson de Andrade Arruda (1980), Vera Lúcia Amaral Ferlini (1988), Laura de Mello e Souza (2006) -, envolvidos com a tese do capitalismo colonial, mais ou menos familiarizados e comprometidos com as categorias analíticas do marxismo. Outros, mesmo sem tratar exclusivamente dos temas ligados à colônia, como Emília Viotti da Costa (1966) e Boris Fausto (1970), permaneceram fortemente vinculados aos desdobramentos da reflexão histórica em questão.

Um dos destaques dessa geração de historiadores é Fernando Novais, tanto pela influência duradoura da obra, Portugal e Brasil na crise do antigo sistema colonial (I877-I808) (1973), como pela importância institucional acadêmica do autor. Em torno dele, a ideia de "antigo sistema colonial" - como categoria analítica mais acabada, de matriz inquestionavelmente marxista, que pretende arrematar e complementar as formulações de Caio Prado Jr. - logrou aproximar o trabalho de vários historiadores e irradiar-se da Universidade de São Paulo (USP) para outros centros de pesquisa em História de todo Brasil.

A crítica, também de extração marxista, às formulações de Fernando Novais, no que concerne ao caráter da economia e administração da sociedade colonial, surgiu já no início da década de 1970, envolvendo primeiramente questões teórico-metodológicas. Ciro Flamarion S. Cardoso (I973, I979, I980, 1987) questiona a precisão lógico-formal no uso da categoria modo de produção e na concepção da empresa capitalista colonial. Também contesta incisivamente a excessiva preocupação com a transferência de excedente para a metrópole e a formulação teleológica segundo a qual a opção pelo trabalho escravo era resultado das vantagens observáveis no comércio atlântico de cativos. Jacob Gorender (1978), por sua vez, desenvolve uma reflexão monumental no campo da economia política para 
apresentar um modelo alternativo de modo de produção específico da sociedade colonial escravista.

Em termos propriamente empíricos, as teses de Fernando Novais foram criticadas a partir da ampliação dos estudos acadêmicos, em curso desde os anos de 1980, que apontavam para a diversidade e complexidade das unidades produtivas, da mão-de-obra, das rotas de comércio e dos investimentos na América portuguesa. Ainda envolvidos com as categorias do marxismo, Maria Yedda Leite Linhares (1979), Francisco Carlos Teixeira da Silva (1979), Hebe Maria de Castro (1987) João Luís Fragoso (I992) e Manolo Florentino (I993) questionam a primazia das variáveis exógenas no processo de estruturação da economia e sociedade no Brasil colonial.

O problema da herança colonial apontava constantemente para outro tema, mais central e caro aos marxistas, a revolução, com reflexos diretos na produção historiográfica ao longo do século XX. Nesse campo, o desafio conceitual a ser enfrentado consistia em delimitar o processo histórico e as principais características da "revolução burguesa" no Brasil, para que se pudesse prognosticar o advento da revolução socialista. Na prática, as análises convergiam para a proposição de que os dois processos aconteceriam simultaneamente ou, pelo menos, próximos e interligados. Mais uma vez, o debate se polarizava, em termos historiográficos, entre uma versão mais oficial, com tendência a reproduzir uma concepção marxista "etapista" da história, e outra mais acadêmica acerca da revolução brasileira.

No primeiro grupo, Nelson Werneck Sodré (1962, 1964, 1990) defendia a tese segundo a qual a revolução brasileira havia começado no contexto da crise dos anos de 1920, quando a burguesia, as classes médias (ou a pequena burguesia) e o proletariado se transformaram em agentes históricos da modernização capitalista, cujo papel principal consistiria em superar a herança social deixada por trezentos anos de escravidão e eliminar definitivamente os resquícios do modo de produção feudal na formação econômico-social brasileira.

Tal processo estaria em aberto ainda na década de 1990, marcado sempre pela posição titubeante da burguesia nacional, ora inclinada simplesmente a promover a manutenção da posição conquistada a partir de I930, encerrando-se no ciclo da revolução burguesa nacional, ora propensa a aliar-se ao proletariado e às forças políticas progressistas, e de esquerda, para promover a revolução brasileira, cujo resultado seria a construção de um Estado nacionalpopular, anti-imperialista e ligado ao bloco mundial socialista existente à época.

Por sua vez, a produção intelectual de Caio Prado Jr. - Evolução política do Brasil e outros estudos (1933), Formação do Brasil contemporâneo (1942), História econômica do Brasil (1945) e A revolução brasileira (I966) - apontava constantemente para o problema da revolução sob 
outro viés analítico. Desde 1933, quando analisou o processo de emancipação política do Brasil, já colocava em destaque a dinâmica da luta de classes, ao sublinhar o conflito entre os interesses das classes dominantes nacionais e as cortes portuguesas, no contexto em que prevalecia a necessidade de conter os movimentos populares de cunho protonacionalistas. As transformações ligadas à independência do Brasil são apresentadas não somente como fruto do desenvolvimento das forças produtivas, mas também como resultado da iniciativa consciente dos sujeitos históricos na ação política (KONDER, 1989, p. I33).

A partir dessa perspectiva, o problema histórico da revolução encontraria ressonância constante na produção acadêmica, principalmente entre cientistas sociais e economistas de algum modo ligados ao marxismo. A avaliação dos movimentos ocorridos principalmente na China e em Cuba produziam oscilações, observáveis nas obras de Fernando Henrique Cardoso (1964), Enzo Faletto (1970) e Florestan Fernandes (1968,1973, 1975), entre uma perspectiva que priorizava a revolução socialista e outra que centrava a análise na questão da dependência.

A preponderância da ideia de capitalismo colonial afastava a hipótese de se pensar a revolução burguesa como um evento histórico singular, similar ao que ocorrera em vários países da Europa, sobretudo na França, e mesmo na América, entre o final do século XVIII e início do século XIX. Pois, tendo nascido sob a égide do capitalismo, o Brasil conheceria sucessivos processos de modernização que mais pareceriam ajustes no caminho a ser percorrido até a estruturação de uma sociedade liberal democrática e burguesa, que serviria de antessala da revolução socialista.

Entre historiadores tais como José Honório Rodrigues (1965), Paula Beiguelman (1967), Carlos Guilherme Mota (1970), Maria Beatriz Nizza da Silva (1988), Ilmar Rohloff Mattos (1990) e Fernando Novais (1996), prevaleceu a ideia de uma revolução burguesa processual, cujas origens remontavam ao processo de emancipação política em I822. Concomitantemente, Leslie Bethel (1976), Robert Conrad (1978), Richard Graham (1979), José de Souza Martins (1979), Paula Beiguelman (I98I), Suely Robles Reis de Queiroz (I98I) e Emília Viotti da Costa (1982) apresentavam a abolição da escravidão e a transição para o trabalho livre como adequações necessárias ao pleno desenvolvimento do modo de produção capitalista, embora não suprimissem a condição colonial ou a subordinação ao imperialismo. Pouquíssimos trabalhos se contrapunham a este eixo interpretativo - Jacob Gorender (1978) e Décio Saes (1985) -, procurando identificar a revolução burguesa no Brasil como evento político mais específico e corolário da transição de um modo de produção não capitalista a outro capitalista dependente.

Naturalmente, o tema da revolução burguesa levava ao tema da industrialização. 


\section{C) Hitsistórica}

Entre meados de 1970 e meados de 1980, Warren Dean (197I), Maria da Conceição de Almeida Tavares (1972), Sérgio Silva (1976), Wilson Cano (1977), Stanley Stein (1979), João Manuel Cardoso de Mello (1982) e Wilson Suzigan (1986) conduziram o debate acadêmico em torno do surgimento da indústria nacional e do início efetivo do processo histórico de industrialização. Em linhas gerais, as obras desses autores evidenciam o diálogo constante com as categorias do marxismo e, principalmente, o interesse de economistas pela história econômica do Brasil. O tema aparece sintetizado na necessidade de se desvendar a forma histórica da relação entre a cafeicultura e a industrialização. O ponto de partida é a noção de que a predominância econômica da cafeicultura, a partir da segunda metade do século XIX, criaria obstáculos constantes ao surgimento e avanço da indústria, interrompidos apenas nos momentos de crise da economia mundial que possibilitariam o desenvolvimento da indústria nacional através da substituição das importações.

Ao longo de duas décadas a produção acadêmica apurou cada vez mais a percepção da relação complexa entre capital cafeeiro e capital industrial, apontando para as consequências estruturais que a relação café-indústria criaria no sentido da dependência econômica no contexto da industrialização. Até certo ponto afastadas desse núcleo de produção acadêmica, embora do mesmo modo voltadas para a reflexão histórica sobre o processo de industrialização, surgiram as contribuições de Nícia Villela Luz (196I), Eulália M. Lahmeyer Lobo (1978) e Sônia Regina de Mendonça (1986).

Paralelamente, ainda dentro dos parâmetros estabelecidos pela reflexão historiográfica marxista, o debate sobre a natureza da revolução burguesa implicou a revisão do teor das análises acerca da chamada "revolução de 1930". De tal modo, o movimento militar que aglutinou os descontentamentos das elites regionais preteridas no jogo político da Primeira República (I889-I930) ganharia novas dimensões analíticas. De movimento das forças armadas de caráter "tenentista”, ou expressão política das camadas médias urbanas, o golpe militar de outubro de 1930 passaria a sustentar o status de ponto culminante da revolução burguesa iniciada com a independência no século XIX. Pois expressava a crise definitiva da hegemonia política da oligarquia agrário exportadora do centro-sul do país, abrindo consigo a possibilidade de ascensão da burguesia industrial ao poder, mesmo que tutorada pelos interesses do capital externo.

O principal protagonista da revisão historiográfica foi Boris Fausto (1970, 1988), para quem a "revolução de I930" representa o evento decisivo da revolução burguesa no Brasil, mesmo levando-se em conta suas peculiaridades como processo longo, mas que guardaria similaridades históricas com as revoluções jacobinas liberais e modernizadoras da Europa e 


\section{C) Hitistór RICA}

América. As categorias usadas como base das proposições remetem à ideia de "via revolucionária para o capitalismo e a democracia” (MOORE JR. 1967).

É importante salientar que, entre os anos de 1950 e 1960, toda uma geração de cientistas sociais ligados principalmente à Universidade de São Paulo (USP), como Celso Furtado, Fernando Henrique Cardoso, Florestan Fernandes e Francisco de Oliveira permanecia um pouco afastada dos domínios restritos da historiografia, embora não deixasse nunca de articular material historiográfico e alguma dose de marxismo em suas formulações. Mais atuantes nas áreas da sociologia e economia, tais autores respondiam aos estímulos políticos e intelectuais resultantes da aproximação com a intelectualidade francesa - especialmente Jean-Paul Sartre, desde finais dos anos de 1950 - e do prestígio alcançado pela CEPAL - Comissão Econômica para a América Latina e o Caribe.

Em 1964, todos foram surpreendidos pelo golpe de Estado e pela consolidação do arcabouço institucional da ditadura militar em dezembro de 1968 (Ato Institucional $\mathrm{n}^{\circ}$ 5). Com efeito, para os intelectuais da esquerda, no final dos anos de 1960, entre várias outras tarefas políticas e intelectuais, impunha-se a necessidade de refletir sobre o esgotamento da experiência democrática estabelecida a partir de 1945, e sobre a participação dos trabalhadores organizados em partidos e sindicatos na crise institucional de 1964 e seus desdobramentos no regime ditatorial militar.

Para tanto, havia a princípio um conjunto vago de formulações inspiradas em parte no marxismo que procurava refletir sobre o processo histórico de incorporação dos trabalhadores urbanos ao cenário político na América Latina. Ou, mais especificamente, refletir sobre o processo histórico pelo qual as elites políticas latino-americanas lograram ampliar cuidadosamente os direitos de cidadania para a maioria da população, a partir dos principais centros urbanos, desde a crise dos anos de 1930, sem colocar em risco o controle que possuíam do processo político, econômico e social. Nesses termos, surgia o debate acadêmico sobre o fenômeno do "populismo" na América Latina e no Brasil.

O quadro histórico acerca da "revolução de 1930", apresentado por Boris Fausto, adequava-se perfeitamente ao conjunto de formulações que procurava dar conta do fenômeno de incorporação dos trabalhadores urbanos ao cenário político ao longo do século $\mathrm{XX}$. As proposições históricas e analíticas ganhariam acabamento e amplitude quando aproximadas dos trabalhos de Ênio Silveira (1968), Octávio Ianni (1968) e Francisco Weffort (1978), sendo este último, sem dúvida, o expoente acadêmico mais proeminente no debate dos anos de 1970 sobre o "populismo". O ponto de partida era a acepção negativa da palavra "populismo", usada pelos contemporâneos para definir um tipo específico de aproximação dos políticos com o povo. A inflexão teórica mais importante foi a ampla utilização do 


\section{C) HitstótóricA}

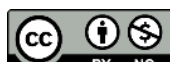

conceito gramsciano de "hegemonia", figurando ao lado da categoria frankfurtiana de "massa", e uma certa concepção de "manipulação" que remetia, ainda que fragilmente, ao conceito pouco elaborado de "ideologia" como mera distorção do real para efeito de dominação.

O modelo lógico-histórico, aplicável tanto para o Brasil como para a América Latrina, ganhou acabamento entre 1970 e 1978, propondo o seguinte esquema analítico: I. a crise econômica nos países mais desenvolvidos do sistema capitalista afetou a economia periférica da América Latina cuja atividade central era a produção agropecuária e de matérias primas para a exportação; 2. a crise econômica levou as oligarquias agrário exportadoras a perder a hegemonia política que sustentavam junto aos aparelhos de Estado desde o século XIX; 3. o resultado imediato da perda da hegemonia política do setor agrário exportador foi o "vazio de poder", na medida em que não havia outro setor da burguesia capaz de assumir por completo a condução política do Estado pela difusão de seus valores e ideologias; 4. em períodos de tempo variáveis, de acordo com as conjunturas nacionais, o vazio de poder foi superado pela emergência de uma espécie de "Estado de compromisso", que procurava manter a estabilidade institucional, conciliar os interesses dos diversos setores das burguesias nacionais em conflito e conter as pressões das classes trabalhadoras urbanas que reivindicavam maior participação política; 5. a precária estabilidade política e social, aliada a ausência de um setor hegemônico entre as elites econômicas, abriria caminho para a possibilidade de ascensão de líderes políticos carismáticos, pouco comprometidos com os principais membros das elites nacionais tradicionais; 6. por fim, os líderes carismáticos, por sua vez, a exemplo de Getúlio Vargas (Brasil), Perón (Argentina) e Cárdenas (México), sustentavam-se no cenário político e no controle do Estado pela capacidade que possuíam de manipular as "massas" ignorantes de trabalhadores urbanos, através da concessão calculada de benefícios sociais, oferecidos principalmente por meio dos sindicatos colaboracionistas, ou "pelegos", em troca de apoio, fidelidade e subserviência política.

A fórmula do "populismo" consagrou-se a tal ponto que até hoje qualquer estudante de história, minimamente preparado, é capaz de reproduzi-la em seus elementos fundamentais. Populismo em meados do século XX: crise da hegemonia do setor agrário exportador, vazio de poder, líder carismático, manipulação política e econômica das massas, servilismo dos trabalhadores sindicalizados.

Importante salientar também que a categoria "populismo" continuou sendo utilizada amplamente como ferramenta explicativa, principalmente por jornalistas e comentaristas políticos dos veículos tradicionais de comunicação da chamada grande imprensa. E serve, via de regra, para caracterizar personagens políticos latino-americanos de grande 
popularidade, eleitos por ampla margem de voto democrático, a exemplo de Luís Inácio Lula da Silva, Hugo Chaves, Evo Morales e Cristina Kirchner, aos quais se pretende imputar ilegitimidade, alegando funcionamento falho da democracia, manipulação ideológica e ignorância dos cidadãos eleitores. E, mais recentemente, o termo voltou a ser usado para identificar líderes políticos de direita no cenário internacional.

Já em 1978, Luiz Werneck Vianna delineia uma série de críticas ao então modelo vigente de interpretação da "revolução de 1930" e procede a releitura aprofundada do conceito de hegemonia em Liberalismo e sindicato no Brasil, que pretende ser um trabalho historiográfico e teórico na mesma medida, aproximando-se das noções de "revolução pelo alto", "revolução sem revolução" e "via prussiana" (MOORE JR. 1967). De tal modo, onde anteriormente Boris Fausto identificava uma crise de hegemonia política, Vianna apreende a ampliação dos laços políticos agregando novos interesses de diferentes setores da burguesia fortalecendo-se mutuamente. Onde se apontava o vazio de poder, detecta-se a expansão da máquina do Estado com o objetivo de ampliar a ingerência e o planejamento articulado dos mais diversos setores da economia e da sociedade. Como resultado, o evento político de 1930, e seus desdobramentos, configura-se como sendo apenas mais um elemento da trajetória secular em que as elites econômicas e políticas do Brasil lograram implementar processos de modernização conservadora. Processos históricos articulados que remontam à conquista pacífica e geograficamente unificada da independência, passando pela abolição lenta e progressiva da escravidão. Processos cujo sentido último consistiria em protelar a concessão de cidadania política para a grande maioria da população com o objetivo de garantir os privilégios da elite, baseados no controle das instituições políticas e na estabilidade institucional, econômica e social.

Havia, concomitantemente, no cenário acadêmico do início dos anos de 1980, uma tendência a aproximar E. P. Thompson, Walter Benjamin e Michael Foucault, cujo resultado para o debate em torno da "revolução de 1930" expressa-se no trabalho de Edgar Salvadori de Decca, O silêncio dos vencidos (198I), para quem o eixo central de interpretação passa a ser a hegemonia dos comunistas entre as instituições e os militantes de esquerda, e como estes se tornaram preza fácil da manipulação do projeto estatal trabalhista implementado por Getúlio Vargas a partir de I93I.

No entanto, ao final da década de 1980, foi a investigação histórica da "revolução de I930" pelo crivo da "modernização conservadora" e a opção pela categoria "trabalhismo" como recurso analítico que abriu caminho para as críticas ao esquema consagrado de explicação do "populismo". A invenção do trabalhismo (1988), de Ângela Maria de Castro Gomes, oferece elementos empíricos e teórico-metodológicos suficientes para questionar de 


\section{G) hitșTórica}

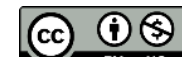

modo substantivo a ideia de manipulação dos trabalhadores domesticados pelas benesses oferecidas pelo governante carismático, supostamente típicas do "populismo" no Brasil, em que o Estado era comumente apresentado como único ator político relevante, capaz de produzir uma identidade de fora e imputá-la aos trabalhadores através de suas lideranças, entre 1930 e 1964. Nesse sentido seu trabalho foi ampliado e complementado pelas contribuições de Daniel Aarão Reis Filho e Jorge Ferreira (200I).

A utilização de autores como William H. Sewell Jr., E. P. Thompson e Adam Przeworski permite a Ângela Maria de Castro Gomes promover uma revisão ampla das abordagens historiográficas centradas na categoria "populismo”, através da incorporação da noção de formação da classe trabalhadora como fenômeno histórico ligado essencialmente à experiência política. $\mathrm{O}$ objeto central da reflexão, sobre a incorporação dos trabalhadores ao processo político no século XX, passa a ser a construção da identidade dos trabalhadores através da re-significação dos valores e tradições operárias multisseculares, em momentos de mudança social. Estabelece-se assim a possibilidade de se estudar a constituição da classe trabalhadora como ator político central de sua própria história, através da análise do processo em que a classe, por meio de numerosas lutas políticas, conseguiu conquistar acesso à cidadania e forjou sua identidade e consciência de classe.

Como resultado analítico, o "trabalhismo" brasileiro, que anteriormente era definido como projeto político e ideológico imposto aos trabalhadores pelo Estado, pela manipulação, passa a carregar outro sentido. Mais especificamente, defende-se que o sucesso do "trabalhismo", enquanto projeto estatal, dependeu de sua capacidade de absorver do discurso articulados dos trabalhadores os elementos-chave de sua auto-imagem, investindoos de novos significados em um novo contexto discursivo, constituindo uma identidade coletiva da classe trabalhadora que articulava uma lógica material (benefícios da legislação social) e uma lógica simbólica (benefícios como doação mediante a luta dos trabalhadores).

Assim sendo, a ideologia trabalhista é definida como resultado da interação entre as demandas dos trabalhadores e as formulações do governo, num jogo de pressões e concessões mútuas, no qual se destaca a expressão política da consciência da classe trabalhadora. Portanto, o advento do "trabalhismo" demarca historicamente a constituição da classe trabalhadora como ator coletivo central do fenômeno cultural e político em que se articulam valores, ideias, tradições e modelos de organização, resultantes da relação de reciprocidade material e simbólica estabelecida entre trabalhadores e Estado, em que os primeiros são ao mesmo tempo sujeito e objeto.

Se todo o debate acadêmico em torno do "populismo" foi impulsionado pela necessidade de explicar as condições sociais e políticas que antecederam e levaram ao golpe 
militar de 1964, não foi diferente com a reflexão sobre o próprio golpe e o regime militar em si, que geraria, entre outras, uma versão historiográfica marxista sobre o fenômeno. Nela prevaleceria a tentativa de relacionar os acontecimentos de $1964 \mathrm{com}$ os determinantes econômico-estruturais, com a expansão do capitalismo internacional, com a luta de classes e com o desempenho político dos diversos setores da burguesia brasileira. Em grande medida, os militares seriam classificados como instrumento da burguesia para efetuar um golpe reacionário e de direita (TOLEDO, I997; FICO, 2004).

Em meio ao universo muito amplo de trabalhos jornalísticos, de teoria política, de avaliações oficiais dos militantes da esquerda e das memórias dos “anos de chumbo", há que se destacar, entre os historiadores marxistas, a contribuição de, pelo menos, três autores para o debate acadêmico historiográfico sobre o golpe.

Jacob Gorender (1987) propõe a análise do estágio de desenvolvimento do capitalismo no Brasil entendido como condicionante do golpe e apresenta a hipótese do caráter preventivo da ação militar diante da improvável revolução comunista no Brasil. Por sua vez, René Dreifuss (198I) entende o golpe militar como ação do "bloco multinacional associado", cujo objetivo é superar a assimetria entre a predominância dos interesses do capital externo no Brasil a ausência de lideranças políticas capazes de assegurar tal predomínio econômico nas esferas institucionais do Estado. Mais recentemente, Daniel Aarão Reis Filho (1989, 200o), avalia historicamente o golpe militar como resultado da crescente aversão, compartilhada por vários setores da burguesia, ao protagonismo crescente das classes trabalhadoras no cenário político do Brasil pós-1945. Aversão capaz de agregar interesses de banqueiros, industriais, latifundiários, comerciantes e vários setores da classe média, além de condicionar o processo de homogeneização ideológica das forças armadas.

Todas as trajetórias da produção historiográfica de inspiração marxista no Brasil, até aqui apresentadas, remetem, direta ou indiretamente, à história da classe trabalhadora como objeto de investigação. Nesse campo específico e ao mesmo tempo abrangente, entendido como área para a qual convergem as pesquisas em história social do trabalho, história social da urbanização e industrialização, história das classes trabalhadoras, história do movimento operário e história dos partidos políticos e sindicatos de esquerda, houve predomínio quase absoluto da abordagem marxista ao longo do século XX.

Em linhas gerais, a "labour history" no Brasil segue um percurso análogo ao apresentado por Eric Hobsbawm (1984) para o caso da Inglaterra.

Entre as décadas de 1930 e 1960, desenvolve-se uma historiografia do movimento operário feita principalmente dentro do próprio movimento e fora das universidades, com tendência a identificar as classes trabalhadoras com o movimento operário organizado, ou 


\section{C) HitșTórica}

mesmo com as lideranças organizadas em partidos e sindicatos, além de atribuir ao movimento operário uma importância que nenhum outro setor na sociedade reconhecia. $\mathrm{O}$ resultado concreto é uma espécie de história oficial do movimento operário, feita a partir de narrativas tradicionais e história institucional de um objeto, à época, pouco convencional, reservado quase sempre aos simpatizantes do marxismo ou da esquerda. Leôncio Basbaum (1957), Otávio Brandão (1978), Everardo Dias (1962), Hermínio Linhares (1977), Astrogildo Pereira (1979) e Jover Telles (I962) são os principais expoentes dessa geração de historiadores.

Em seguida, a história operária ganha espaço nas universidades com os trabalhos pioneiros de Paulo Sérgio Pinheiro (1975, 1979), Maria Nazareth Ferreira (1978), Eulália Maria Lahmeyer Lobo (1978), Edgard Carone (I979, I989), Sheldon Leslie Maram (I979), Michael Hall (1979), Francisco Foot e Victor Leonardi (1982). No entanto, em grande medida, os objetos permanecem restritos à história do movimento operário e das lideranças organizadas, principalmente em função dos acervos de documentos disponíveis, quase sempre de caráter oficial ou relativos à imprensa operária.

Paulatinamente, ao longo dos anos de 1970 e 1980, o avanço das pesquisas estabelece o predomínio dos estudos da formação histórica das classes trabalhadoras. E assim surgem Trabalho urbano e conflito social (I890-1920) de Boris Fausto (1977), A classe operária no Brasil (I889-1930) de Paulo Sérgio Pinheiro e Michael Hall (I98I), Classe operária, sindicatos e partido no Brasil de Ricardo Antunes (I982), A formação da classe trabalhadora de Maria da Conceição Pinto de Góes (1989) e Rio de Janeiro operário de Eulália Maria Lahmeyer Lobo (1992).

Na década de 1980 a historiografia marxista demarca uma alteração significativa nos parâmetros até então vigentes na pesquisa da história operária. Sob a influência da obra de E. P. Thompson, acerca do chamado fenômeno histórico de formação da classe trabalhadora, configura-se o predomínio dos temas e abordagens que privilegiam a luta de classe no universo do cotidiano e da cultura dos trabalhadores, em autores como Francisco Foot Hardman (1983), Margareth Rago (1985), Sidney Chalhoub (1986) e Maria Auxiliadora Guzzo Decca (1987).

Dentro desse mesmo movimento, Ângela Maria de Castro Gomes (1988) e Cláudio Batalha (I988, I990, I992 I999), investem no sentido de relativizar a ideia de predomínio do socialismo, do anarquismo e do comunismo no movimento operário da Primeira República, estabelecendo um elo analítico que facilita a compreensão do advento do trabalhismo.

Mais recentemente, trabalhos tais como A historiografia da classe operária no Brasil: trajetória e tendências (1998) de Cláudio Batalha, Culturas de classe: identidade e diversidade na formação do operariado (2004) organizado por Cláudio Batalha, Fernando Teixeira da Silva e Alexandre Fortes e As esquerdas no Brasil (2007) organizado por Jorge Ferreira e Daniel Aarão 
Reis Filho somam-se ao repertório das obras envolvidas na revisão iniciada na segunda metade dos anos de 1980 .

Qualquer avaliação do desempenho da historiografia, marxista ou não, dedicada à análise dos "mundos do trabalho" no Brasil deve incluir a produção voltada para a história da escravidão, por razões obvias (CHALHOUB; SILVA, 2009). No entanto, paradoxalmente, ao longo do século XX, em grande medida o debate acadêmico sobre a escravidão aparece como um subtema da análise do processo de formação econômica e da administração da América portuguesa (Brasil colonial), com exceção dos trabalhos dedicados mais especificamente à Abolição.

Seja como for, assim como no campo relativo à história da classe trabalhadora, no que tange à escravidão houve predomínio evidente das abordagens marxistas, principalmente entre os anos de 1960 e 1990. Tal influência pode ser dividida em dois períodos precisos, separados pela ampla revisão promovida na segunda metade da década de 1980 (CARDOSO, 1988; GORENDER, 1990). No entanto, para compreender o debate sobre a escravidão é necessário recuar aos anos de 1930.

Entre a primeira edição de Casa Grande e Senzala, em I933, e o início da década de 1950, Gilberto Freyre conseguiu transformar-se no sociólogo brasileiro mais conhecido, mais traduzido e mais citado, dentro e fora da universidade, no Brasil e no exterior. Seu prestígio monumental sustenta-se, até hoje, pela capacidade que teve de identificar e evidenciar as raízes africanas da cultura brasileira, de promover a crítica contundente da ideia de inferioridade da "raça negra" e de combater o projeto político elitista de branqueamento da população como "solução" dos problemas da nação no início do século XX. O argumento político e acadêmico de Freyre estrutura-se a partir de dois princípios analíticos articulados: o caráter patrimonial e benigno da escravidão luso-brasileira e a vigência da democracia racial no Brasil - esta última entendida como capacidade de convivência cordial e pacífica entre os vários grupos que compõem a sociedade multirracial brasileira.

Apesar do caráter imponente do trabalho de Freyre, os anos de 1950 assistiriam ao surgimento de um viés concorrente na interpretação da história da escravidão e da questão racial. Pois, entre historiadores, sociólogos e antropólogos, reunidos em torno da chamada "escola sociológica paulista", articula-se a preocupação com a investigação empírica da violência e da dureza das condições de trabalho e da vida sob o regime escravista. Ao mesmo tempo, difunde-se a necessidade de promover o debate político e acadêmico acerca perenidade do preconceito racial e da efetiva descriminação. Coube inicialmente a autores como Florestan Fernandes (1955, 1971, 1975) e Roger Bastide (1955, 197I) o empenho em promover a crítica cerrada à interpretação que faz Gilberto Freyre da escravidão no Brasil. 


\section{C) Gitistór RICA}

A partir de 1960 surge uma linhagem de trabalhos historiográficos que procura destacar a violência sistêmica nas relações sociais típicas do escravismo colonial, ao mesmo tempo em que pretende dar visibilidade aos registros históricos de fuga e revolta dos escravos. Consequentemente, o marxismo ocupa um lugar de destaque como referência teórica entre os principais autores desse amplo conjunto de interpretações históricas da escravidão, exercendo uma influência constante, embora as vezes difusa nas obras de Fernando Henrique Cardoso, Capitalismo e escravidão no Brasil meridional (I962), Octávio Ianni, As metamorfoses do escravo (I962) e Raças e classes sociais no Brasil (I966) e Emília Viotti da Costa, Da senzala a colônia (I966).

Em linhas gerais a historiografia marxista sobre escravidão demarca a centralidade da categoria trabalho, para o entendimento do processo de formação econômica e social do sistema escravista, e privilegia a análise dos aspectos evidentes da luta de classes, entre senhores e escravos, como a revolta explicita contra a escravidão e a fuga do cativeiro.

Nos anos de 1970, a aproximação com autores americanos e do Caribe, entre eles Eugene Genovese, Orlando Patterson, Manuel Moreno Fraginals e Eric Foner expande o espectro da análise marxista. A produção historiográfica sobre a escravidão se renova e amplia-se vertiginosamente com os trabalhos de Décio Freitas (I971, I976, I980, I983, I985), Clóvis Moura (1972, 198I, 1987), Leslie Bethel (1976), Suely Robles de Queiroz (1977, I98I, I987) Ciro Flamarion S. Cardoso (1979, 1982, 1987), Richard Graham (1979), Emília Viotti da Costa (1982) e Paulo Sérgio Pinheiro (1983).

Na segunda metade dos anos de I980, com a aproximação do centenário da abolição, os trabalhos acadêmicos sobre escravidão ganharam um destaque considerável, impulsionados pelo aumento do interesse coletivo pelo assunto e a consequente ampliação do financiamento das pesquisas nas universidades. $\mathrm{O}$ incremento da pesquisa ocorreu tendo à frente uma nova geração de historiadores cujo perfil teórico-metodológico permanecia próximo do marxismo, no entanto, um marxismo bastante específico, que se pretendia renovado e contemplando os temas da cultura, mais do que da economia. E. P. Thompson aparece como referência principal. O resultado mais geral desse movimento é o abandono dos parâmetros analíticos sustentados durante décadas pelo binômio "violência e revolta".

Silvia Hunold Lara, Campos da violência (1988), Sidney Chalhoub, Visões da liberdade (1990), Hebe Maria Mattos de Castro, Das cores do silêncio (1995) e Robert Slenes, Na senzala, uma flor (1999) são os principais protagonistas da revisão historiográfica da escravidão. Paulatinamente, a partir do final dos anos de I980, outros autores colocam em evidência a busca de autonomia e as estratégias cotidianas de resistência dos escravos, assim como as concepções dos cativos acerca da justiça, da liberdade e da própria escravidão. A 
preocupação com o resgate histórico da subjetividade dos escravos, da "luta de classes sem classe" e do paternalismo nas relações sociais levaria ao predomínio das formulações que destacam a "resistência e acomodação" dos escravos ao sistema social escravista. Entretanto, torna-se mais difícil distinguir com precisão a influência do marxismo nos textos de Célia Maria Marinho de Azevedo (1987), Maria Helena Pereira Toledo Machado (1987, 1994), Leila Mezan Algranti (1988), João José Reis (1988, 1989, 1996), Marilene Rosa Nogueira da Silva (1988), Eduardo Silva (1989), Flávio dos Santos Gomes (I995, 1996).

\section{A crise da crise ou o fim?}

O Brasil vivenciou, no final dos anos de 1980, o fim do regime ditatorial civil-militar e o advento de um partido de massas de esquerda afastado dos princípios do comunismo nacional e internacional, que agregava os novos sindicatos, os movimentos sociais do campo e das cidades e os setores progressistas da Igreja Católica. Tudo isso, em meio a uma crise econômica sem precedentes, cujo resultado final seria a ampliação da concentração de renda, o empobrecimento da grande maioria da população e a delimitação mais acabada de uma conjuntura ideológica favorável ao neoliberalismo.

Fora do Brasil, o desaparecimento definitivo da União Soviética e a queda do muro de Berlim sinalizavam, do ponto de vista histórico, o fim da experiência socialista "real" e o início de um longo, e até hoje em curso, recuo da predominância dos princípios do racionalismo, do iluminismo e, consequentemente, do marxismo entre historiadores e cientistas sociais. Era também o fim do "breve século XX". Para muitos, foi o fim da modernidade e da escrita da história a ela vinculada.

Entretanto, neste mesmo período, a historiografia brasileira transformou-se rapidamente em disciplina acadêmica completamente institucionalizada, dentro de um sistema universitário que se organizava desde os anos de 1970 e, ao final dos anos 1980 , se consolidou, se expandiu e se diversificou vertiginosamente. Entre os resultados imediatos desse processo, atinentes à produção historiográfica, pode-se verificar um conjunto de tendências importantes, embora de caráter muito geral.

Houve uma considerável diminuição da influência da historiografia francesa e o avanço no sentido da pluralidade dos referenciais teórico-metodológicos adotados pelos historiadores, mesmo que, muitas vezes, por caminhos duvidosos, como, por exemplo, quando se ensaiou uma aproximação entre E. P. Thompson, Walter Benjamin e Michel Foucault. Ao mesmo tempo, chegaram ao Brasil os debates sobre a Nova História Cultural, a História Social do Trabalho e a Micro-História. 


\section{C) GitistóñICA}

Por outro lado, a produção sistemática de pesquisas de caráter monográfico com extensa base empírica, dentro dos novos programas de pós-graduação, afetou e comprometeu definitivamente o padrão até então predominante de formulações explicativas, lógico-históricas, típicas da historiografia das décadas anteriores. Passou a ser comum, no ambiente acadêmico, um trabalho monográfico, bem realizado e empiricamente embasado, questionar de forma veemente todo edifício lógico histórico, em geral elaborado com base no marxismo, construído por autores consagrados ao longo das décadas anteriores. Assim, as formulações clássicas foram sistemática e convincentemente contestadas a partir de estudos regionais com amostragens empíricas relevantes. E, na maior parte das vezes, o universo da crítica atribuía ao vínculo com o marxismo o equívoco da proposição criticada.

Por fim, uma das demandas mais generalizadas da reflexão histórica nos anos de 1980 foi a necessidade de se promover a crítica e a superação das proposições consideradas estruturalistas. Entre os historiadores marxistas disseminou-se a proposta ampla de se resgatar o papel do sujeito na história, entre os vários outros "resgastes" a que se propunham - como, por exemplo, o resgate da "história dos vencidos". Consequentemente, depois de três décadas, alguns segmentos da historiografia debruçam-se, exclusivamente, sobre a história dos sujeitos individuais.

Em termos mais específicos, alguns campos da disciplina da História no Brasil, amplamente demarcados pelo marxismo, conheceram um esvaziamento quase completo. Temas e objetos tais como a natureza do modo de produção e da formação econômico-social, a dinâmica dos sistemas econômicos, a transição para o capitalismo e o caráter da revolução burguesa, praticamente, desapareceram da pauta de pesquisa da história econômica e social. O estudo da industrialização, por exemplo, converteu-se em grande medida em história de empresas e da ação de agentes individuais dentro do sistema financeiro.

No tradicional campo de estudos da formação econômica e administração da América portuguesa (Brasil colonial), os anos de 1970 demarcaram o debate e a revisão das teses de Caio Prado Jr. e Fernando Novais, ainda dentro do espectro das concepções teóricas marxistas. A partir dos anos I990, as formulações que pretendiam superar o paradigma do "sentido da colonização" e do "antigo sistema colonial" incorporaram diversos outros referenciais teóricos, passando de Witold Kula para Karl Polanyi, de Marcel Mauss para Giovani Levi, Frederic Barth e António Manuel Hespanha.

Entre os estudos sobre a escravidão, depois do período marcado pelo revisionismo, I980-1990, observa-se uma tensão latente entre, por um lado, os herdeiros e promotores das revisões - na maior parte, ainda inspiradas por E. P. Thompson - e, por outro lado, uma tendência vigorosa de revitalizar as teses de Gilberto Freyre. Mais recentemente algo 
próximo da micro-história, ou da análise de trajetórias de indivíduos, também se estabeleceu nos estudos da escravidão.

No campo de investigação relativo à formação das classes trabalhadoras e ao movimento operário houve uma ampliação considerável da produção e, principalmente a ampliação das regiões priorizadas pelas pesquisas, abrangendo, além de São Paulo e Rio de Janeiro, centros urbanos importantes a partir do século XIX em Minas Gerais, Rio Grande do Sul, Pernambuco e Bahia. Também ocorreu a difusão de estudos sobre o cotidiano e a cultura dos trabalhadores, muitas vezes orientados pelos paradigmas teóricos da escolha racional, de Mancur Olson, Albert O. Hirschman e Adam Przeworski. No entanto, o predomínio do marxismo, especificamente de matiz thompsoniana, permanece inconteste.

Observada desta perspectiva, a historiografia marxista parece estar vivendo hoje apenas mais uma crise, marcada por recuos e revisões.

O marxismo no Brasil não acompanhou todos os desdobramentos, a expansão e as variações que o marxismo conheceu ao longo do século XX. No entanto, são inegáveis a presença constante, a importância e a influência predominante ao longo de cinquenta anos na historiografia. Não há dúvidas de que o marxismo forneceu o principal conjunto de formulações teórico-metodológicas cuja influência foi predominante na historiografia brasileira entre os anos de 1930 e 1990.

Essa influência ocorreu não somente por meio do corolário de proposições políticas revolucionárias de esquerda baseadas na análise pragmática da economia e da sociedade. Também não era o simples resultado da contemplação filosófica diletante de intelectuais ligados à universidade e inspirados no materialismo histórico e dialético.

O predomínio do marxismo na historiografia dependeu da amalgama de elementos políticos, conceituais e institucionais não redutíveis ao marxismo. Dependeu de algo que se pode definir como um processo de construção da cultura universitária de excelência nos moldes franceses, atrelado ao predomínio da história econômica e social inspirada nos Annales, num ambiente em que a disciplina da história dialogava constantemente com a sociologia, economia, filosofia e com a cultura militante comunista e de esquerda, onde predominava a concepção de História como Ciência Social.

E foi tudo isso, e não somente o marxismo, que entrou em crise nos anos de 1980 e parece estar definhando rapidamente ainda hoje. Foi esse o conjunto mais amplo de elementos, que definiram a historiografia brasileira por cinco décadas, que entrou em colapso.

Portanto, não seria correto falar simplesmente em hegemonia do marxismo na historiografia brasileira entre 1930 e I990, mesmo quando se admite que foi a influência 


\section{C) Hitistór RICA}

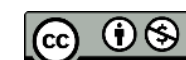

teórica predominante. Seria mais adequado falar em predomínio, ou hegemonia, de um conjunto de elementos políticos, conceituais e institucionais marcados profundamente pela reflexão marxista no Brasil.

Todos os elementos desta configuração, que permitiu o predomínio do marxismo na historiografia, transformaram-se radicalmente entre meados da década de 1980 e meados de I990 e não voltarão a se articular como antes.

No que diz respeito aos poucos historiadores marxistas ainda existentes, o problema central talvez seja perceber que a crise que atualmente enfrentam está ocorrendo dentro de um panorama de crise muito maior, a grande crise dos parâmetros que orientaram a produção historiográfica no Brasil ao longo do século XX, da qual, talvez, não seja possível escapar, sendo ou não marxista.

Por fim, resta uma questão importante: qual será o desempenho da História da Historiografia ao avaliar, num futuro próximo, por exemplo, o apego de Laura de Melo e Souza à categoria "antigo sistema colonial", ou a defesa da "economia-mundo" proposta por Rafael Marquese, ou ainda a recente utilização que Sidney Chalhoub faz de categorias tais como "ideologia senhorial" e "hegemonia política e cultural"? Serão considerados indícios da persistência, do vigor, da decadência ou da crise da crise do marxismo na historiografia brasileira?

\section{Referências bibliográficas}

ALGRANTI, Leila Mezan. O feitor ausente: estudos sobre escravidão urbana no Rio de Janeiro - I808-I822. Petrópolis: Vozes, I988.

ANDERSON, Perry. Considerations on Western Marxism. London: Verso, 1979. . In the tracks of Historical Materialism. London: Verso, 1983.

. A crise da crise do Marxismo; introdução a um debate contemporâneo. São Paulo: Brasiliense, 1984 .

. Considerações sobre o Marxismo Ocidental. Porto: Afrontamento, I989.

. A Zone of Engagement. London / New York: Verso, 1992.

Perry. The Origins of Postmodernity. London / New York: Verso, 1998.

Perry. Spectrum: From Right to Left in the World of Ideas. London / New York: Verso, 2005.

ANDERSON, Perry; CAMILLER, Patrick. Mapping the West European Left. London / New York: Verso, 1994.

ANTUNES, Ricardo. Classe operária, sindicatos e partido No Brasil; da revolução de trinta até a Aliança Nacional Libertadora. São Paulo: Cortez, 1982. 
ARANTES, Paulo Eduardo. Sentimento de dialética na experiência intelectual brasileira. Rio de Janeiro: Paz e Terra, 1992.

ARRUDA, José Jobson de Andrade. O Brasil no comércio colonial. São Paulo, Ática, I980.

AZEVEDO, Célia Maria Marinho de. Onda negra, medo branco: o negro no imaginário das elites - século XIX. Rio de Janeiro: Paz e Terra, I987.

BASBAUM, Leôncio. História sincera da República. 4 volumes. Rio de Janeiro: Livraria São José, 1957.

Uma vida em seis tempos: memórias. São Paulo, Alfa-Ômega, 1976.

BASTIDE, Roger. Brasil, terra de contrastes. São Paulo: Difel, I959.

BASTIDE, Roger; FERNANDES, Florestan. Relações raciais entre negros e brancos em São Paulo. São Paulo: Anhembi, 1955. . Brancos e negros em São Paulo. São Paulo: Nacional, I97I.

BATALHA, Cláudio H. M. História social em questão. História: Questões \& Debates, Curitiba, v.9, n.I7, dez-I988, pp. 229-24I.

- Uma outra consciência de classe? O sindicalismo reformista na Primeira República. Ciências Sociais Hoje, I990, São Paulo: Vértice / Editora dos Tribunais, pp. II7-I27.

Identidade da classe operária no Brasil (I880-1920): Atipicidade ou Legitimidade?, Revista Brasileira de História, São Paulo, v. I2, n² 23/24, set. 9I/ago. 92, pp. III-I24.

A difusão do marxismo e os socialistas brasileiros na virada do século XIX. In: MORAES, João Quartim de (Organizador). História do Marxismo no Brasil II; os influxos teóricos. Campinas: Editora da Unicamp, 1995. p.II-44.

A historiografia da classe operária no Brasil: trajetória e tendências. In: FREITAS, M. C. de (Organizador.). Historiografia brasileira em perspectiva. Bragança Paulista: Ed. da USF; São Paulo: EDUSP: Contexto, I998.

Sociedades de Trabalhadores no Rio de Janeiro do século XIX: algumas reflexões em torno da formação da classe operária. Cadernos AEL: sociedades operárias $e$ mutualismo. Campinas: IFCH/Unicamp, v. 6, n. Io/II, I999, pp. 4I-68.

BATALHA, Claudio H. M.; SILVA, Fernando Teixeira da; FORTES, Alexandre (Organizadores.). Culturas de classe: identidade e diversidade na formação do operariado. Campinas: Editora da Unicamp, 2004.

BEIGUELMAN, Paula. Formação política do Brasil. São Paulo: Pioneira, 1967. A crise do escravismo e a grande imigração. São Paulo: Brasiliense, I98I.

BETHEL, Leslie. A abolição do tráfico de escravos no Brasil. Rio de Janeiro: Expressão e Cultura / São Paulo: Edusp, 1976. 
BRANDÃO, Otávio. Combates e batalhas. Alfa-Ômega, 1978.

CANO, Wilson. Raízes da concentração industrial em São Paulo. São Paulo: Difel, I977.

CARDOSO, Ciro Flamarion S. Observações sobre o ‘dossier’ preparatório da discussão sobre o modo de produção feudal. In: C.E.R.M. Sobre o feudalismo. Lisboa: Editorial Estampa, I973. p. 7I-73.

Sobre los modos de producción coloniales de América. In: CARAVAGLIA, Juan Carlos (Organizador). Modos de producción em América Latina. Mexico: Siglo XXI Editores, 1973. p. 135-160.

. Agricultura, escravidão e capitalismo. Petrópolis: Vozes, 1979.

As concepções acerca do sistema econômico mundial: a preocupação obsessiva com a extração do excedente. In: LAPA, José Roberdo do Amaral (Organizador). Modos de produção e realidade Brasileira, Petrópolis, Vozes, I980. p. I09-I32.

. A Afro-América; escravidão no novo mundo. São Paulo: Brasiliense, 1982.

. Escravo ou camponês? protocampesinato negro nas Américas. São Paulo: Brasiliense, 1987.

. (Organizador). Escravidão e Abolição no Brasil; novas perspectivas. Rio de Janeiro: Jorge Zahar Editor, 1988.

CARDOSO. Ciro Flamarion S.; BRIGNOLI, Héctor. História econômica da América Latina. São Paulo: Graal, 1983.

CARDOSO, Fernando Henrique de. Capitalismo e escravidão no Brasil meridional. São Paulo: Difusão Européia do Livro, 1962.

Capitalismo e escravidão no Brasil meridional; o negro na sociedade escravocrata do Rio Grande do Sul. São Paulo: Difel, 1962. . Empresário industrial e desenvolvimento econômico. São Paulo: Difel, 1964.

CARDOSO, Fernando Henrique; FALETTO, Enzo. Dependência e desenvolvimento na América Latina. Rio de Janeiro: Zahar, 1970.

CARONE, Edgard. Movimento operário no Brasil: 1877-1944. São Paulo: Difel, 1979. . Classes sociais e movimento operário. São Paulo: Ática, 1989.

CASTRO, Hebe Maria de. Ao sul da história. São Paulo: Brasiliense, I987.

CASTRO, Hebe Maria Mattos de. Das cores do silêncio: significados da liberdade no sudeste escravista - Brasil século XIX. Rio de Janeiro: Arquivo Nacional, 1995.

CHALHOUB, Sidney. Trabalho, lar e botequim; o cotidiano dos trabalhadores no Rio de Janeiro da Belle Époque. São Paulo: Brasiliense, 1986. 


\section{C) HitșTórICA}

. Visões da liberdade: uma história das últimas décadas da escravidão na corte. São

Paulo: Companhia das Letras, 1990.

. Machado de Assis: historiador. São Paulo: Companhia das Letras, 2003.

. A força da escravidão; ilegalidade e costume no Brasil oitocentista. São Paulo: Companhia das Letras, 2012.

CHALHOUB, Sidney; SILVA, Francisco Teixeira da. Sujeitos no imaginário acadêmico: escravos e trabalhadores na historiografia brasileira desde os anos 1980. Cadernos AEL, V.I4, n.26, 2009, pp. I3-47.

CONRAD, Robert. Os últimos anos da escravatura no Brasil: I850-I888. Rio de Janeiro: Civilização Brasileira, 1978.

COSTA, Emília Viotti da. Da senzala à colônia. São Paulo: Difel, I966.

Da Monarquia à República; momentos decisivos. São Paulo: Brasiliense, 1977. . A abolição. São Paulo: Global, 1982.

DEAN, Warren. A industrialização de São Paulo, I880-1945. São Paulo: Difel, I97I.

DECCA, Edgar Salvadori de. O silêncio dos vencidos. São Paulo: Brasiliense, I98I.

DECCA, Maria Auxiliadora Guzzo. A vida fora das fábricas. Rio de Janeiro: Paz e Terra, I987.

DIAS, Everardo. História das lutas sociais no Brasil. São Paulo: Edaglit, 1962.

DREIFUSS, René Armand. 1964: A conquista do Estado; ação política, poder e golpe de classe. Rio de Janeiro: Vozes, I98I.

ERICKSON, Kenneth Paul. Sindicalismo e processo político no Brasil. São Paulo: Brasiliense, I979.

FAUSTO, Boris. A Revolução de I930: história e historiografia. São Paulo: Brasiliense. I970. . Trabalho urbano e conflito social (I890-I920). São Paulo: Difel, I977.

. Estado, trabalhadores e burguesia (1920-1945): uma revisão. Novos Estudos CEBRAP, São Paulo, n. 20, março, 1988.

FERLINI, Vera Lúcia Amaral. Terra, trabalho e poder; o mundo dos engenhos no Nordeste colonial. São Paulo: Brasiliense, 1988.

FERNANDES, Florestan. Sociedade de classes e subdesenvolvimento. Rio de Janeiro: Zahar, 1968. . Capitalismo dependente e sociedade de classes na América Latina. Rio de Janeiro: Zahar, I973.

. A revolução burguesa no Brasil. Rio de Janeiro: Zahar, 1975.

. A integração do negro na sociedade de classes. São Paulo: 1978.

FERREIRA, Jorge (organizador). O populismo e sua história; debate e crítica. Rio de Janeiro: Civilização Brasileira, 200I. 
FERREIRA, Jorge; REIS FILHO, Daniel Aarão (Organizadores). As esquerdas no Brasil: a formação das tradições (I889-I945), volume I. Rio de Janeiro: Civilização Brasileira, 2007.

FERREIRA, Maria Nazareth. A imprensa operária no Brasil: I890-I920. Petrópolis: Vozes, I978. FICO, Carlos. Além do golpe; a tomada do poder em 3I de março de I964 e a ditadura militar. Rio de Janeiro: Record, 2004.

FLORENTINO, Manolo. Em costas negras; uma história do tráfico atlântico de escravos entre África e o Rio de Janeiro. Rio de Janeiro: Arquivo Nacional, I995.

. Tráfico, cativeiro e liberdade; Rio de Janeiro, séculos XVII-XIX. Rio de Janeiro: civilização Brasileira, 2005.

. (Organizador). Tráfico, cativeiro e liberdade. Rio de Janeiro: Civilização Brasileira, 2005.

FLORENTINO, Manolo; MACHADO, Cacilda. (Organizadores). Ensaios sobre escravidão (I). Belo Horizonte: Editora UFMG, 2003.

FOOT, Francisco; LEONARDI, Victor. História da Indústria e do Trabalho no Brasil (das origens aos anos 20). São Paulo: Global, 1982.

FRAGOSO, João Luís Ribeiro. Homens de grossa aventura; acumulação e hierarquia na praça mercantil do Rio de Janeiro (I790-I830). Rio de Janeiro: Arquivo Nacional, 1992.

FRAGOSO, João; FLORENTINO, Manolo. O arcaísmo como projeto: mercado atlântico, sociedade agrária e elite mercantil no Rio de Janeiro, c. I790 - c. I840. Rio de Janeiro: Diadorim, 1993.

FRAGOSO, João; BICALHO, Fernanda; GOUVÊA, Maria de Fátima (Organizadores). O Antigo Regime nos trópicos; a dinâmica imperial portuguesa (séculos XVI-XVIII). Rio de Janeiro: Civilização Brasileira, 200I

FRAGOSO, João; FLORENTINO, Manolo; SAMPAIO, Antônio Carlos Jucá de; CAMPOS, Adriana Pereira (Organizadores). Nas rotas do império; eixos mercantis, tráfico e relações sociais no mundo português. Vitória: Edufes; Lisboa: IICT, 2006.

FRAGOSO, João Luís Ribeiro; ALMEIDA, Carla Maria Carvalho; SAMPAIO, Antônio Carlos Jucá de (Organizadores). Conquistadores e negociantes; histórias de elites no Antigo Regime nos trópicos. América lusa, séculos XVI a XVIII. Rio de Janeiro: Civilização Brasileira, 2007.

FRAGOSO, João; GOUVÊA, Maria de Fátima (Organizadores). Na trama das redes; política e negócios no império português, século XVI-XVII. Rio de Janeiro: Civilização Brasileira, 2010.

FREITAS, Décio. Palmares; a guerra dos escravos. Porto Alegre: Movimento, I97I. 


\section{G) GitșTórICA}

. Insurreições escravas. Porto Alegre: Movimento, 1976.

. O escravismo brasileiro. Porto Alegre: Vozes, 1980.

. Escravos e senhores de escravos. Porto Alegre: Mercado Aberto, 1983.

. A Revolução dos Malês. Porto Alegre: Movimento, 1985.

FURTADO, Celso. Formação econômica do Brasil. Rio de Janeiro: Fundo de Cultura, 1959.

Brasil: tempos modernos. São Paulo: Paz e Terra, 1968.

GÓES, Maria da Conceição Pinto de. A formação da classe trabalhadora; movimento anarquista, I888-I9II. Rio de Janeiro: Jorge Zahar Editor / Fundação José Bonifácio, I989.

GOMES, Ângela Maria de Castro. A invenção do trabalhismo. São Paulo: Vértice, Editora Revista dos Tribunais; Rio de Janeiro: Instituto Universitário de Pesquisa do Rio de Janeiro, 1988.

GOMES, Flávio dos Santos. História de quilombolas; mocambos e comunidades de senzalas no Rio de Janeiro - século XIX. Rio de Janeiro: Arquivo Nacional, 1995.

Experiências atlânticas; ensaios e pesquisa sobre escravidão e pós-emancipação no

Brasil. Passo Fundo: UPF, 200I.

GORENDER, Jacob. O escravismo colonial. São Paulo: Ática, 1978.

. A escravidão reabilitada. São Paulo: Ática, 1990.

. Combate nas trevas. As esquerdas brasileiras; das ilusões perdidas à luta armada.

São Paulo: Ática, 1987.

GRAHAM, Richard. Escravidão, reforma e imperialismo. São Paulo: Brasiliense, 1979.

GUIMARÃES, Alberto Passos de. Quatro séculos de latifúndio. São Paulo: Fulgor, 1964.

GUIMARÃES, Carlos Gabriel. A presença inglesa nas finanças e no comércio no Brasil imperial.

Rio de janeiro: Alameda Casa Editorial, 2012.

HARDMAN, Francisco Foot. Nem pátria, nem patrão; memória operária, cultura e literatura no Brasil. São Paulo: Brasiliense, 1983.

HOBSBAWM, Eric J. Labour History and Ideology. In: Workers; worlds of labor.

New York: Pantheon Books, 1984.

IANNI, Octávio. As metamorfoses do escravo. São Paulo: Difel, 1962.

. Raças e classes sociais no Brasil. Rio de Janeiro: Civilização Brasileira, I966.

. O colapso do populismo no Brasil. Rio de Janeiro: Civilização Brasileira, 1968.

- A formação do Estado populista na América Latina. São Paulo: Ática, 1989.

KONDER, Leandro. A façanha de uma estreia. In: D’Incao, Maria Angela (Organizadora). História de um ideal; ensaios sobre Caio Prado Jr. São Paulo: Brasiliense/Unesp, I989. p. I33. 


\section{C) HitșTórICA}

LAMBERT, Jaques. Os dois Brasis. São Paulo: Cia. Editora Nacional, 1967.

LAPA, José Roberto do Amaral (Organizador). Modos de produção e realidade brasileira. Petrópolis: Vozes, 1980.

LARA, Silvia Hunold. Campos da violência; escravos e senhores na capitania do Rio de Janeiro, I750-I808. Rio de Janeiro: Paz e Terra, I988.

. Fragmentos setecentistas; escravidão, cultura e poder na América portuguesa. São Paulo: Companhia das Letras, 2007.

LINHARES, Hemínio. Contribuição às lutas operárias no Brasil. São Paulo: Alfa-Ômega, 1977.

LINHARES, Maria Yedda Leite. História do abastecimento; uma problemática em questão (I530-I9I8). Brasília: Binagri, I979.

LINHARES, Maria Yedda Leite; SILVA, Francisco Carlos Teixeira da. História da agricultura brasileira. São Paulo: Brasiliense, s/d.

LOBO, Eulália M. Lahmeyer. História do Rio de Janeiro; do capital comercial ao capital industrial e financeiro. 2 vol. Rio de Janeiro: IBMEC, 1978.

(Organizadora). Rio de Janeiro operário; natureza do Estado, a conjuntura econômica, condições de vida e consciência de classe, I930-I970. Rio de Janeiro: Access Editora, 1992.

LUZ, Nícia Vilela. A Luta pela Industrialização do Brasil. São Paulo: Difusão Européia do Livro, I96I.

MACHADO, Maria Helena Pereira Toledo. Crime e escravidão; trabalho, luta e resistência nas lavouras paulistas, I830-I888. São Paulo: Brasiliense, 1987.

. O plano e o pânico; os movimentos sociais na década da abolição. Rio de Janeiro: Editora UFRJ / Edusp, 1994.

MARAM, Sheldon Leslie. Anarquistas, imigrantes e movimento operário no Brasil. Rio de Janeiro: Paz e Terra, 1979.

MARQUESE, Rafael de Bivar. Feitores do corpo, missionários da mente. São Paulo: Companhia das Letras, 2004.

MATTOS, Ilmar Rohloff. Tempo Saquarema: formação do Estado imperial. $2^{\mathrm{a}}$ ed. São Paulo: Hucitec, 1990.

MELLO, João Manuel Cardoso de. O capitalismo tardio. São Paulo: Brasiliense, 1982.

MENDONÇA, Sônia Regina de. Estado e economia no Brasil: opções de desenvolvimento. Rio de Janeiro: Graal, 1986.

MOORE JR., Barrington. Social Origins of Dictatorship and Democracy: Lord and peasants in the making the modern world. Boston: Beacon Press, 1967. 
MORAES FILHO, Evaristo de. A proto-história do marxismo no Brasil. In: REIS FILHO, Daniel Aarão [et al.]. História do Marxismo no Brasil I; o impacto das revoluções. Rio de Janeiro: Paz e Terra, 199I. p.I5-46.

MOTA, Carlos Guilherme (Organizador). Brasil em perspectiva. São Paulo: Difusão Européia do Livro, 1969.

Atitudes de inovação no Brasil. Lisboa: Livros Horizontes, 1970.

MOTA, Carlos Guilherme; NOVAIS, Fernando. A independência política do Brasil. São Paulo: Hucitec, 1996.

MOURA, Clóvis. Rebeliões da senzala; quilombos, insurreições e guerrilhas. Rio de Janeiro: Conquista, 1972. . Quilombos e rebelião negra. São Paulo: Brasiliense, I98I. . Quilombos; resistência ao escravismo. São Paulo: Ática, 1987.

NOVAIS, Fernando Antônio. Portugal e Brasil na crise do antigo sistema colonial (I877-I808). São Paulo: Hucitec, 1978.

PEREIRA, Astrogildo. Ensaios históricos e políticos. São Paulo: Alfa-Ômega, I979.

PINHEIRO, Paulo Sérgio. Política e Trabalho no Brasil. Rio de Janeiro: Paz e Terra, 1975. (organizador). Trabalho escravo, economia e sociedade. Rio de Janeiro: Paz e Terra, 1983.

PINHEIRO, Paulo Sérgio; HALL, Michael. A classe operária no Brasil, I889-I930; Documentos. v. I. São Paulo: Alfa-Ômega, 1979.

A classe operária no Brasil, I889-I930: Documentos, v. II: condições de vida e de trabalho, relações com os empresários e o Estado. São Paulo: Brasiliense, I98I.

PRADO JR., Caio. Formação do Brasil contemporâneo. São Paulo: Brasiliense, 1942. História econômica do Brasil. São Paulo: Brasiliense, 1945. Evolução política do Brasil e outros estudos. São Paulo: Brasiliense, I953. A revolução brasileira. São Paulo: Brasiliense, 1966.

QUEIROZ, Suely Robles de. Escravidão negra em São Paulo; um estudo das tensões provocadas pelo escravismo no século XIX. Rio de Janeiro: José Olympio, I977. A abolição da escravidão. São Paulo: Brasiliense, 198I. .. A escravidão negra no Brasil. São Paulo: Ática, 1987.

RAGO, Margareth. Do cabaré ao lar; a utopia da cidade disciplinar. Rio de Janeiro: Paz e Terra, 1985.

REIS FILHO, Daniel Aarão. A revolução faltou ao encontro; os comunistas no Brasil. São Paulo; Brasília: Brasiliense; CNPq, 1989.

Ditadura militar, esquerdas e sociedade. Rio de Janeiro: Jorge Zahar, 2000. 
REIS, João José (Organizador). Escravidão E invenção da liberdade; estudos sobre o negro no Brasil. São Paulo: Brasiliense / CNPq, 1988.

REIS, João José; SILVA, Eduardo. Negociação e conflito: a resistência negra no Brasil escravista. São Paulo: Companhia das Letras, 1989.

REIS, João José; GOMES, Flávio dos Santos (Organizadores). Liberdade por um fio: história dos quilombos no Brasil. São Paulo: Companhia das Letras, I996.

REIS, João José; GOMES, Flávio dos Santos; CARVALHO, Marcus Joaquim. O Alufá Rufino; tráfico, escravidão e liberdade no Atlântico Negro (c. I822-c. I853). São Paulo: Companhia das Letras, 2010.

RODRIGUES, José Honório. Conciliação e reforma no Brasil; um desafio histórico-cultural. Rio de Janeiro: Civilização Brasileira, 1965.

. Independência; revolução e contra-revolução. 5 vol. Rio de Janeiro: Francisco Alves, 1975.

SAES, Décio. A formação do Estado burguês no Brasil: I888-I89I. Rio de Janeiro: Paz e Terra, 1985.

SILVA, Maria Beatriz Nizza da. Formas de representação política na época da independência. Brasília: Câmara dos Deputados, 1988.

SILVA, Marilene Rosa Nogueira da. Negro na rua: a nova face da escravidão. São Paulo: Hucitec, 1988.

SILVA, Sérgio. Expansão cafeeira e origens da indústria. São Paulo: Alfa-Ômega, 1976.

SLENES, Robert W. Na senzala, uma flor; esperanças e recordações na formação da família escrava, Brasil Sudeste, século XIX. Rio de Janeiro: Nova Fronteira, I999.

SODRÉ, Nelson Werneck. Introdução à revolução Brasileira. Rio de Janeiro: José Olympio, I958.

. Formação histórica do Brasil. São Paulo: Brasiliense, 1962.

História da Burguesia Brasileira. Rio de Janeiro: Civilização Brasileira, I964.

. Capitalismo e revolução burguesa no Brasil. Belo Horizonte: Oficina de Livros, I990.

SOUZA, Laura de Mello e. O Sol e a Sombra: política e administração na América portuguesa do século XVIII. São Paulo: Companhia das Letras, 2006.

STEIN, Stanley. Origens e evolução da indústria têxtil no Brasil. Rio de Janeiro: Campus, 1979.

SUZIGAN, Wilson. Indústria brasileira. São Paulo: Brasiliense, I986.

TAVARES, Maria da Conceição de Almeida. Da substituição de importações ao capitalismo financeiro. Rio de Janeiro: Zahar Editores, 1972.

Acumulação de capital e industrialização no Brasil. Campinas: Editora da Unicamp, 1986. 
THOMPSON, E. P. The making of the english working class. New York: Vintage Books, 1966.

THOMSON, E. P. Whigs and hunters; the origin of the Black Act. London: Allen Lane, 1975.

TOLEDO, Caio Navarro (Organizador). I964: visões críticas do golpe; democracia e reformas no populismo. Campinas: Unicamp, 1997.

VIANNA, Luiz Werneck. Liberalismo e sindicato no Brasil. Rio de Janeiro: Paz e Terra, 1978.

WEFFORT, Francisco. O populismo na política brasileira. São Paulo: Paz e Terra, I978.

ZAIDÁN, Michel. O Grande Tounant: O VI congresso da Internacional Comunista (I928I929). In: REIS FILHO, Daniel Aarão [et al.]. História do Marxismo no Brasil I; o impacto das revoluções. Rio de Janeiro: Paz e Terra, I99I. p. 99-Ioo.

ŽIŽEK, Slavoj. In Defense of Lost Causes. London / New York: Verso, 2009. p. 345.

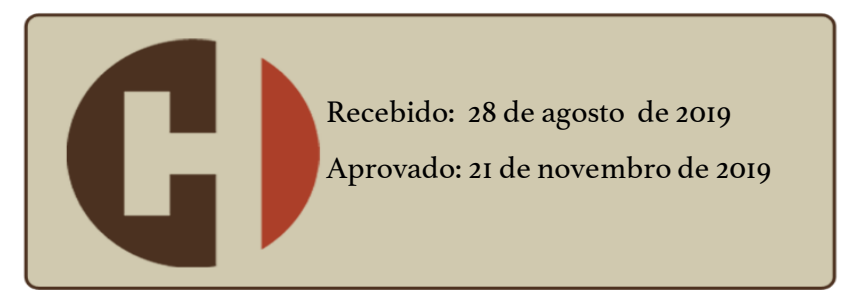

